\title{
TECHNICAL EFFICIENCY OF RAINFED AND IRRIGATED RICE PRODUCTION IN TANZANIA ${ }^{\dagger}$
}

\author{
JOSEPH MKANTHAMA ${ }^{1 *}$, GODSWILL MAKOMBE ${ }^{2}$, JOHN KIHORO ${ }^{3}$, ELIJA M. \\ ATEKA $^{1}$ AND MATSHIDISO KANJERE ${ }^{4}$ \\ ${ }^{1}$ Jomo Kenyatta University of Agriculture and Technology, Nairobi, Kenya \\ ${ }^{2}$ Gordon Institute of Business Science, University of Pretoria, Johannesburg, South Africa \\ ${ }^{3}$ The Cooperative University of Kenya, Nairobi, Kenya \\ ${ }^{4}$ University of Limpopo, Polokwane, South Africa
}

\begin{abstract}
Tanzania produces rice from two major ecologies; namely irrigated and rainfed lowland. Currently most of the rice is produced from the rainfed lowland but the country's National Rice Development Strategy (NRDS) aspires to reverse this trend. The NRDS aspires to increase rice production area for irrigated lowland ecology from 200,000 ha in 2008 to 390,000 ha by 2018 with productivity increasing from 2.13 tons per ha in 2008 to 3.5 tons per ha in 2018 . This study evaluated the performance of irrigated and rainfed lowland rice production using technical efficiency. This paper estimates the technical efficiency of rice production in Tanzania for the irrigated and rainfed lowland ecologies. Data were collected from one irrigated site in Bagamoyo and one lowland rainfed site, Dakawa in the Morogoro area. The study found that the average technical efficiency of the irrigated farmers is $96 \%$ compared to an average $39 \%$ for the rainfed lowland system. For the irrigated system, there are no farmers with technical efficiency less than $80 \%$. The high technical efficiency indicates that in order to achieve the aspired rice production targets, the opportunity for increasing production therefore lies in changing the production technology.
\end{abstract}

KEY WORDS: technical efficiency; irrigated; rainfed; smallholder.

\footnotetext{
${ }^{\dagger}$ L'efficacité technique du riz pluvial ou irrigué en Tanzanie

* Correspondence to: Mr. Joseph Mphatso Mkanthama. Jomo Kenyatta University of Agriculture and Technology. P.O. Box 62000-00200, Nairobi 00200, Kenya. E-mail: mkanthamaj@gmail.com.
} 


\section{RÉSUMÉ}

La Tanzanie produit du riz pluvial irrigué. Actuellement, la majeure partie du riz provient des plaines pluviales, mais la stratégie nationale de développement du riz (NRDS) du pays aspire à inverser cette tendance en augmentant la superficie rizicole irriguée de 200000 ha en 2008 à 390000 ha d'ici 2018, pour une productivité passant de 2,13 tonnes par ha en 2008 à 3,5 tonnes par hectare en 2018. Cette étude a évalué la performance des plaines irriguées et pluviales -qui correspondent à deux écosystèmes bien distincts- en utilisant l'efficacité technique,. Les données ont été recueillies à partir d'un site irrigué à Bagamoyo et d'un site pluvial, Dakawa dans la région de Morogoro. L'étude a révélé que l'efficacité technique moyenne des agriculteurs irrigués était de $96 \%$, et de $39 \%$ en moyenne pour les systèmes de la plaine pluviale. Il n'y a pas d'agriculteurs irrigants ayant une efficacité technique inférieure à $80 \%$. L'efficacité technique élevée indique que, pour atteindre les objectifs de production de riz, l'augmentation de la production réside donc par la modification de la technologie de production.

MOTS CLES : efficacité technique : agriculture pluviale ; agricilture irriguée ; petit exploitant.

\section{INTRODUCTION}

Tanzania has a land area of 94.5 million ha of which $47 \%$ is arable. Currently only $23 \%$ of the arable land is utilised for agriculture showing that Tanzania has great potential to increase agricultural production (Government of Tanzania, 2009). For the 2009/2010 growing season, the total area under rice production was estimated to be $5 \%$ of the 21 million hectares potentially suitable for rice production (Government of Tanzania, 2009). It is also estimated that $18 \%$ of the households in agriculture are engaged in rice production (Government of Tanzania, 2009). The agriculture and fishing sector is a strong contributor to Growth Domestic Product (GDP). The share of GDP from the agriculture and fishing sector averaged just over $25 \%$ during the period 2005 to 2011 in constant 2001 prices.

The contribution of agriculture to GDP shows the importance of the agricultural sector to Tanzania's economy and the government of Tanzania's agriculture development programs emphasise this importance. The declining per capita GDP makes it imperative for the government of Tanzania to focus on broad based programs that reach the majority of Tanzanians in an effort to increase their incomes and reduce poverty. One of the programs under the agricultural sector meant to increase agricultural production is the Kilimo Kwanza program 
(Government of Tanzania, 2009). As part of this agricultural sector development program, the government plans to increase rice production. The plans for rice production are articulated in the National Rice Development Strategy (NRDS) (Government of Tanzania, 2009).

The NRDS identifies the key areas to achieving the rice production objectives as, improving accessibility of improved varieties and seed systems, fertilizer marketing and distribution, irrigation and investments in water control technologies, access to and maintenance of agricultural equipment, post-harvest and marketing, research, technology dissemination and capacity building and access to credit/agricultural finance. This paper estimates the technical efficiency of rice production in Tanzania for the irrigated and rainfed lowland ecologies. Irrigated agriculture in Tanzania is dominated by smallholder traditional systems producing mainly rice and vegetables where irrigation efficiency is quite low, estimated at 14-20\% (Government of Tanzania, 2009).

\section{BACKGROUND}

\section{Trend in rice production and consumption in Tanzania}

Rice is the most important food crop of the developing world and the staple food of more than half of the world's population (Sinha and Talati, 2006). In Tanzania, it is estimated that $60 \%$ of the population consumes rice or rice products each day (Bucheyeki, et al., 2011). Figure 1 shows trends in rice production, consumption, area and yield for the period 1998 to 2007. Over this period, annual rice production in Tanzania averaged 0.62 million metric tons of milled rice. It increased by $54 \%$ from 0.53 million tons in 1998 to 0.82 million tons in 2007. The increase was due to both area and yield increases. Rice area increased by $36 \%$ from an average 0.49 million ha in 1998 to 0.66 million ha in 2007 while yield increased from an average 1.08 t/ha in 1998 to $1.23 \mathrm{t} / \mathrm{ha}$ in 2007 , an increase of $14 \%$. 


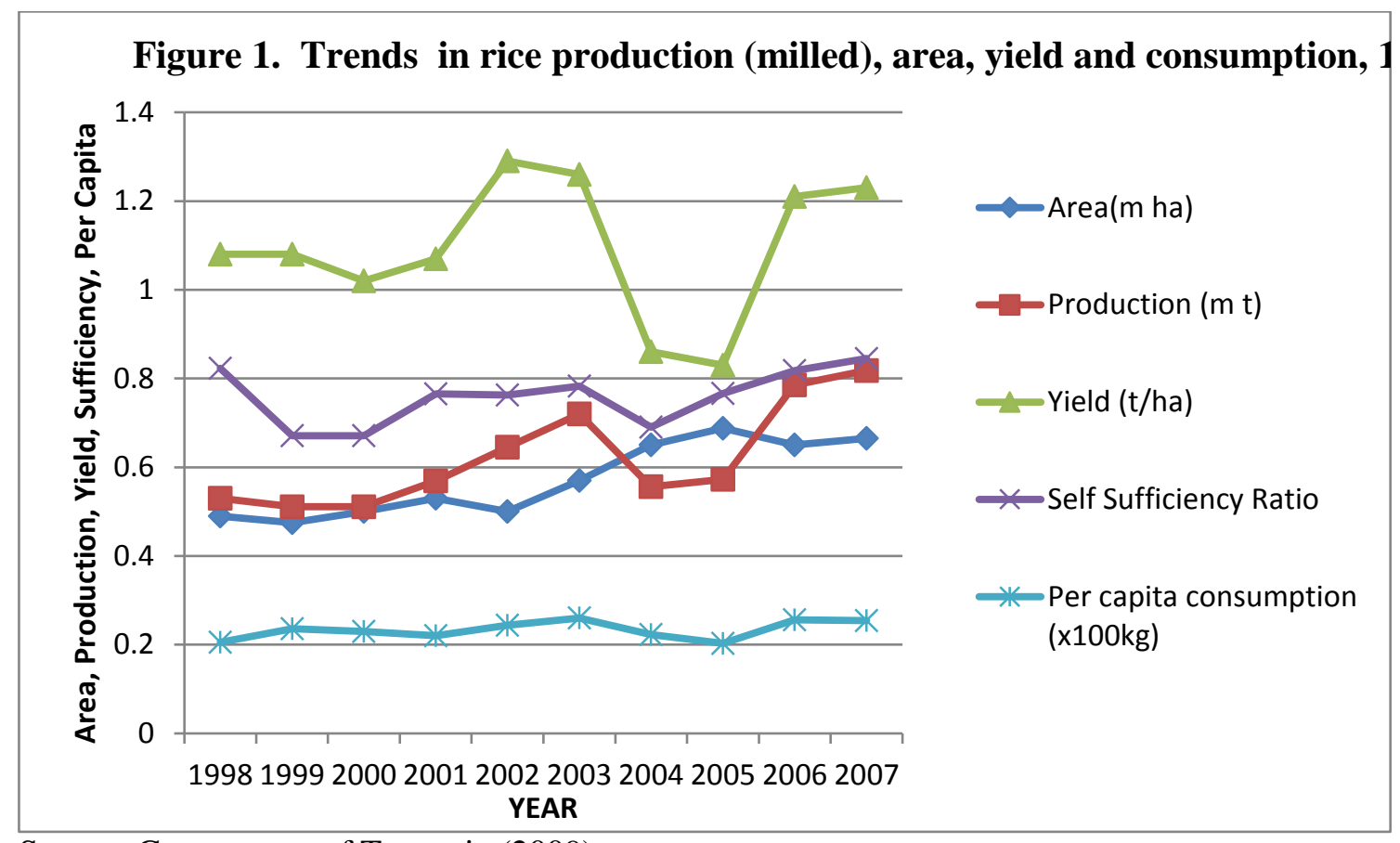

Source: Government of Tanzania (2009)

Over the same period, per capita rice consumption in Tanzania increased by $24 \%$ from 20 $\mathrm{kg}$ to $25 \mathrm{~kg}$ while the self-sufficiency ratio only improved slightly by $3 \%$ from 0.82 in 1998 to 0.84 in 2007 showing that Tanzania is still running a deficit in rice production. However, trends in these parameters for the period 2008 to 2012 need to be analysed in light of these trends. The NRDS spells out the aspirations for increasing rice production as shown in Table I.

Even given the gains in yield described above, one of the major challenges of rice production in Tanzania is low yield especially for rainfed lowland rice production, a major contributor to rice production in the country. Table I shows that rainfed lowland rice yield was estimated at 1t/ha in 2008, and according to the NRDS is anticipated to increase to $2 \mathrm{t} / \mathrm{ha}$ in 2018. During the same period, irrigated rice yield is anticipated to increase from an estimated $2.13 \mathrm{t} / \mathrm{ha}$ in 2008 to $3.5 \mathrm{t} / \mathrm{ha}$ in 2018 . The strategy for increasing rice yield in Tanzania will be based on improved varieties, input intensification (especially for irrigated production), improved husbandry practices and better extension. Figure 2 shows the anticipated trend in percent contribution to area and production for the two major rice production ecologies of rainfed lowland and irrigated. There is a third rice producing ecology, namely; rainfed upland but by 2018 it is still anticipated to still produce insignificant amounts of rice. The irrigated area under rice is expected to increase from $29 \%$ of total in 2008 to $56 \%$ of total in 2013 while production is expected to increase from $47 \%$ of total in 2008 to $70 \%$ of total in 2018 . Concurrently the area contribution of rainfed lowland is expected to decrease from $68 \%$ of total in 2008 to $39 \%$ of 
Table I. Distribution of projected production by ecology 2013 and 2018.

\begin{tabular}{|c|c|c|c|c|c|c|c|c|c|c|c|c|}
\hline Year & \multicolumn{3}{|c|}{ Rainfed upland } & \multicolumn{3}{|c|}{ Rainfed lowland } & \multicolumn{3}{|c|}{ Irrigated } & \multicolumn{3}{|c|}{ Total } \\
\hline & $\begin{array}{c}\text { Area } \\
\text { (1000 ha) }\end{array}$ & $\begin{array}{l}\text { Yield } \\
(\mathrm{t})\end{array}$ & $\begin{array}{c}\text { Production } \\
(1000 t)\end{array}$ & $\begin{array}{c}\text { Area } \\
\text { (1000 ha) }\end{array}$ & $\begin{array}{c}\text { Yield } \\
\text { (t) }\end{array}$ & $\begin{array}{l}\text { Production } \\
(1000 \mathrm{t})\end{array}$ & $\begin{array}{c}\text { Area } \\
\text { (1000 ha) }\end{array}$ & $\begin{array}{c}\text { Yield } \\
\text { (t) }\end{array}$ & $\begin{array}{c}\text { Production } \\
(1000 \mathrm{t})\end{array}$ & $\begin{array}{c}\text { Area } \\
\text { (1000 ha) }\end{array}$ & $\begin{array}{c}\text { Yield } \\
\text { (t) }\end{array}$ & $\begin{array}{l}\text { Production } \\
(1000 \mathrm{t})\end{array}$ \\
\hline 2008 & 17 & 0.5 & 9 & 464 & 1.0 & 464 & 200 & 2.13 & 426 & 681 & 1.3 & 899 \\
\hline 2013 & 21 & 1 & 21 & 374 & 1.5 & 561 & 290 & 3 & 870 & 685 & 2.1 & 1452 \\
\hline 2018 & 31 & 1.6 & 50 & 274 & 2 & 548 & 390 & 3.5 & 1365 & 695 & 2.8 & 1963 \\
\hline
\end{tabular}

Source: Government of Tanzania (2009) 
total in 2018. Its contribution to total rice production is expected to decrease from $52 \%$ in 2008 to $28 \%$ in 2018.

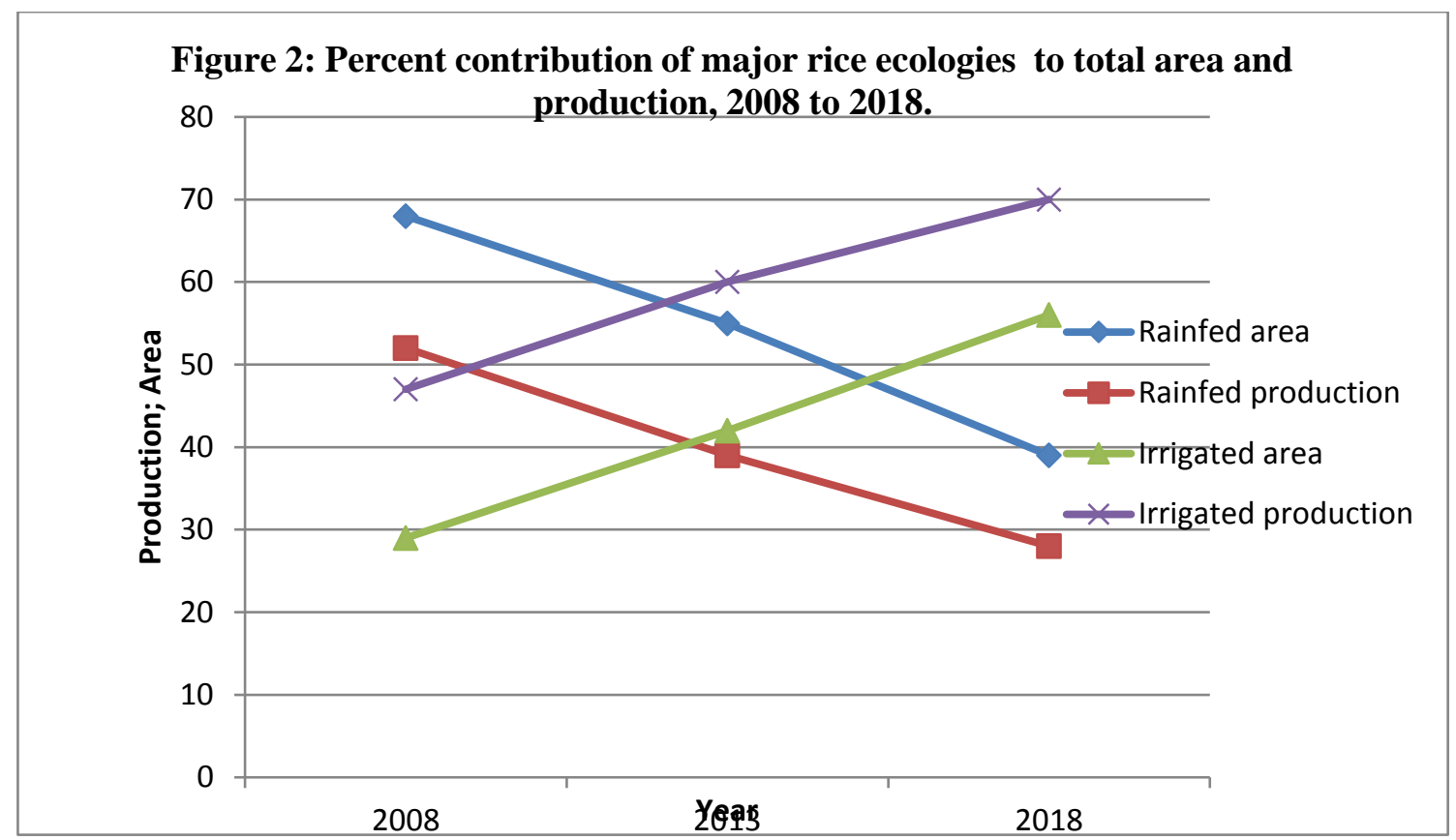

\section{METHODOLOGY}

\section{Data collection}

Data were collected from one irrigated site in Bagamoyo and one lowland rainfed site in Dakawa in the Morogoro area. The two sites are representative of the two ecologies and are used for breeding experiments by the Africa Rice Centre (Africa Rice) and the International Rice Research Institute (IRRI) which conduct rice research in Tanzania. The study used a total sample of 171 plots from 142 farmers. On the irrigation scheme in Bagamoyo the sampling frame used was the list of farmers growing rice in the scheme. In 2011, 40 farmers from the irrigation scheme were proportionately selected by male and female owned plots and then randomly within the genders. At the rainfed site, 5 rice growing villages nearest to the experimental sites were selected and households lists were then drawn with the assistance of the local leaders. From the household list, rice growing households were selected and female and male headed rice growing households were identified. From the rice growing households in Dakawa, 40 farmers were selected proportionally by the number of rice growing households in each village and by the proportions of male and female headed rice growing households in a village then randomly within the gender. Thus, a combined total of 80 farmers were selected in 2011. In the same year, all the 80 farmers selected were trained by Africa Rice and IRRI in good 
agricultural practices in rice growing. The training took the form of a four hour lecture covering all the aspects of rice production from variety choice to harvesting. At each site, farmers also visited a demonstration site where they could visually see the differences between good agricultural practices taught in the training and farmer practices in the area.

In 2012 an additional 40 farmers were similarly selected from each site using the same sampling frames but without replacing the farmers who were trained in 2011. The additional 80 farmers were not trained.

During the 2012 growing season, plot level production data, including varieties, area, labour, fertilizer, and yield were collected from both trained and non-trained farmers. Data were also collected on credit use by farmers, market access, education, age, market access, extension, and membership to farmer organisation.

Some problems were experienced with the sample. In both areas, by the time the survey was conducted in 2012, some of the farmers who had been trained in 2011 had relocated, leased their land or simply did not grow rice in 2012. The program used for analysis also requires that the data be a full matrix without missing values. After accounting for all the factors, this resulted in an effective sample of 92 plots from 68 farmers on the irrigated sites and 79 plots from 74 farmers from the low land rainfed site. There were farmers with multiple plots and there was more multiple plot ownership at the irrigated site.

\section{Technical efficiency estimation}

The stochastic frontier production function approach, generally referred to as the stochastic frontier approach (SFA) is used to estimate technical inefficiency of firms or farms in this study. Aigner and Lovell (1977) and Meeusen and Van den Broeck (1977) concurrently developed the SFA. Aigner and Lovell (1977) specified the stochastic production function as follows:

$Y_{i t}=f\left(X_{i t}, b_{t}\right)+e_{i t}, i=1, \ldots, N$

where $\mathrm{Y}_{\mathrm{it}}$ is the output of the $\mathrm{i}^{\text {th }}$ firm in time $t, \mathrm{X}_{\mathrm{it}}$ is vector of inputs, and $\mathrm{b}_{\mathrm{t}}$ is a vector of production function parameters. $\mathrm{e}_{\mathrm{i}}$ is an error term made up of two components such that:

$e_{i}=v_{i}-u_{i}$

The error term, $\mathrm{v}_{\mathrm{i}}$ in equation 2 is assumed to be a symmetric disturbance that is independently distributed as $\mathrm{N}\left(0, \sigma_{\mathrm{v}}^{2}\right)$. This error term is thought to exist due to two sources 
namely, favorable and unfavorable external shocks out of the firms control and errors of measurement. This part of the error term makes the frontier stochastic as firms can temporarily be above the frontier if the value of $\mathrm{v}_{\mathrm{i}}$ is large enough (Aigner and Lovell, 1977).

The error term $u_{i}$ is assumed to be independent of $v_{i}$ and meets the condition that $u_{i}>0$, which means that it is truncated above zero. It is this error term that provides deviations from the frontier or technical inefficiency. The negative sign in equation 2 along with positive values of $u_{i}$ result in negative deviations from the frontier for each of the observations. In their original paper, this error term has been modeled as a half-Normal and also as an exponential distribution (Aigner and Lovell, 1977).

The specification of the frontier production function used in this study is:

$\mathrm{Y}=(\mathrm{A}, \mathrm{L}, \mathrm{F}, \mathrm{HD}, \mathrm{ID})$

where:

$\mathrm{Y} \quad=$ rice yield in $\mathrm{kg} / \mathrm{ha}$.

$\mathrm{A}=$ plot area

$\mathrm{L} \quad=$ labour in mandays

$\mathrm{F} \quad=$ fertiliser applied to the plot in $\mathrm{kg}$.

Herbicide use dummy $(1=$ yes, $0=$ No $)$

Insecticide use dummy $(1=$ yes, $0=$ No $)$

Water, as an input and water management practices are not included as variables in equation 3. Makombe et al. (1998) analyse the water management performance in smallholder irrigation systems in Zimbabwe. They state, 'For the small holder systems the challenges faced by the managers are first that of matching water demand and supply, and second making sure that farmers apply the water efficiently without waste. A third concern is that managers also want to supply the water in a timely manner' (p. 255). Matching crop water demand and supply can be achieved by measuring the amount of water applied to the whole scheme or to blocks of schemes using cutthroat flumes and then using a method like the modified Penman method to estimate demand as was done by Makombe et al. (1998). However, estimating water applied at plot level is not easy because usually, for smallholder irrigation systems, in-field canals are not lined. Even where they are lined, measuring water flows cannot be achieved by a method like a cutthroat flume but requires measurement using flow metres. Such an exercise becomes very expensive to the extent it becomes difficult to justify.

In an attempt to address this concern, Makombe et al. (2001) and Makombe et al. (2017) 
use the number of times the crops are irrigated as a proxy for water applied. This approach is possible only when there are distinct times when water is applied in order to alleviate moisture stress. In irrigated rice, this approach, or even attempting to measure the amount of water applied to a plot in irrigated rice, is complicated by the fact that water is flooded throughout the scheme or a block of plots and for some time the aim of successful irrigation is to keep the plot flooded. It is perhaps because of the difficulty of estimating the water applied to individual plots, especially in rice flood irrigation, that in the studies such as Idiong (2007), Al-hassan (2008), and Donkoh et al. (2013), water and water management are not included as inputs in the estimation of the technical efficiency. In the case of Bagamoyo irrigation scheme, the extension gave the farmers messages about how to combine the applied water with other inputs like fertilizer and herbicide.

Addressing this issue is important. Given the inapplicability of the approach by Makombe et al. (1998) and Makombe et al. (2017) to irrigated rice perhaps if a study is conducted across schemes, the amount of water applied to a scheme could be measured, say using cutthroat flumes and a method such as the modified Penman method could be used to estimate water application timeliness. A scheme level index of water use and management, which can be used in the SFA, could then be developed. This approach is not possible when studying farmers from one scheme such as in this study.

The estimation of the SFA can be done as a one or two step procedure. It has been recognized that the two step procedure gives biased estimates due to misspecification bias in the first step, a bias substantial enough to strongly argue against the two step estimation procedure (Wang and Schmidt, 2002).

The model for the one step estimation can be specified as:

$Y=f(X) T E(X ; z)$

where:

$\mathrm{X}=$ the vector of inputs to produce output $\mathrm{Y}$.

$\mathrm{TE}(\mathrm{X} ; \mathrm{z})=$ The output oriented measure of technical efficiency and

$\mathrm{Z}=$ = the vector of explanatory variables associated with the technical efficiency (Batesse and Coelli, 1995).

In this study, the vector of z's constituted gender $(0=$ female; $1=$ male $)$, credit use by farmers $(1=$ credit; $0=$ no credit $)$, market access $(1=$ easy access; $0=$ difficult access $)$, education $(1=1$ year of education or more; $0=$ no education), age (in years), extension $(1=$ 
extension contact; $0=$ no extension contact $)$, membership to farmer organisation $(1=$ member of at least one farmer organisation, $0=$ no membership to farmer organisation and $\operatorname{training}(1=$ attended one day training; $0=$ did not attend one day training).

We can also test whether the variance of $u_{i}$ in equation 2 is equal to zero. If the variance of $u_{i}$ is equal to zero this means that $u_{i}=0$ and thus production lies on the frontier. This means that production is technically efficient and deviations from the frontier are a result of a combination of favorable and unfavorable external shocks out of the farms' control and errors of measurement.

Maximum likelihood is used to estimate the parameters for equation 1 and to estimate the variance parameter given by:

$\sigma^{2}=\sigma_{\mathrm{v}+}^{2} \sigma^{2}$

and

$\gamma=\sigma^{2}{ }_{u} / \sigma^{2}$

The likelihood ratio (LR) test, with a mixed Chi-square distribution is used to test the Null hypothesis that $\gamma=0$ and hence $e_{i}=v_{i}$. (Kodde and Palm, 1986). Kodde and Palm (1986) also provide the critical limits of the mixed Chi-Squared test for testing this hypothesis. If the computed LR statistic is above the critical limit, given the degrees of freedom and the significance level $(\alpha)$, then we reject the Null, otherwise we fail to reject it. From this test, if we fail to reject the Null hypothesis that $\gamma=0$, this implies that there are no inefficiency effects $\left(u_{i}\right.$ $=0$ ) which means that the model can be efficiently estimated using OLS (Battese and Coelli, 1995). Frontier 4.1 was used to estimate the stochastic production functions.

\section{Literature review on $S F A$}

Aigner and Lovell (1977) and Meeusen and Van den Broeck (1977) clearly define the concept of the SFA to estimate technical inefficiency. Because of the relationship that:

Technical efficiency $=1$-technical inefficiency

As explained by Makombe et al. (2011) many researchers refer simply to technical efficiency. Technical efficiency (TE), is concerned with how efficiently inputs are combined to produce output (Boateng, 2014, Gebremichael and Gessesse, 2016). It is measured as a ratio of 
actual to potential output (Donkoh et al., 2013). This is the ratio of the farm's actual output to its maximum frontier output for a given level of inputs and chosen technology' (Maurice et al.,). An efficient producer is one who produces the maximum possible (potential) output given a set of inputs or one who uses the least inputs in producing a given output. Makombe et al. (2011) also offer a simplified interpretation and explanation of technical efficiency.

A detailed literature survey of the application of the SFA to both cross sectional and panel data is provided by a number of studies (Battese, 1992; Bravo-Ureta and Pinheiro, 1993; Makombe et al,. 2001). Other studies have provided a meta-analysis from the application of the approach to estimating technical inefficiency in developing country agriculture (Thiam et al., 2001).

The SFA can be applied to any production system where the inputs are clearly identifiable and measurable. Boateng (2014) applied the concept to education in South Africa. Using the SFA to production and institutions in Africa, Adkins et al. (2002) arrive at the conclusion that increases in economic freedom are associated with improved economic performance in that increases in economic freedom move countries closer to the production frontier'. Mujeyi et al. (2016) used the SFA to estimate the technical efficiency of the informal manufacturing sector in Zimbabwe while Gebremichael and Gessesse (2016) applied the SFA to microfinance institutions in 36 African countries. Van Heerden and Van Der Westhuizen (2008) used the concept to estimate the technical efficiency of the banking sector in South Africa. This shows the diversity of the study areas in which the SFA can be applied.

The approach has been widely applied in agriculture. Using SFA, Makombe et al. (2017) estimated the technical efficiency of rainfed systems and compared it to that of irrigated system. During the rainy season, both rainfed and irrigated systems grew cereals like maize, teff, sorghum, wheat, barley and oil seeds like rape seed and niger seed. During the dry season on the irrigated systems farmers grew leafy green vegetables, onions, tomatoes and carrots which were not grown on the rainfed systems. The estimated technical efficiency of modern irrigation systems was $71 \%$ and that of rainfed farmers, who did not have access to irrigation, was $78 \%$. However, the frontier for the irrigated systems was higher than that of rainfed systems. In a study in Adamawa State of Nigeria Maurice et al. (2015) found technical efficiency averaging $66 \%$ among food producing small-scale farmers. They identified eleven cropping systems which included mixed cropping systems. Giroh et al. (2012) found a mean efficiency of 54\% among women rubber tappers in Nigeria. A study on an irrigated vegetable based mixed-cropping production system in South Africa by Mkhabela (2005) found technical efficiency of $84 \%$.

In our literature search, we found more literature on the application of SFA to rice production in Nigeria than any other African country. Perhaps this is as a result of the fact that 
Nigeria is the largest rice producer in West Africa and that demand for rice in Nigeria is rising (Rahman et al., 2013; and Ataboh et al., 2014). Ogundele and Okoruwa (2006) conducted a study in four states in Nigeria, namely; Kaduna, Niger, Ebonyi and Ekiti which were selected because they produced $70 \%$ of the total rice in Nigeria between 2000 and 2003 . The technical efficiencies for non-irrigating farmers who grew traditional rice varieties and those who grew improved varieties were estimated to be 90 and $91 \%$ respectively. Ogundele and Okoruwa (2006) concluded that given the high technical efficiencies, there was little room to improve rice production by improving technical efficiency. However, since yields were low, averaging 1.1t/ha and 1.4t/ha for traditional and improved technology farmers respectively, Ogundele and Okoruwa (2006) concluded that technological change was needed to increase yields and therefore shift the production frontier outwards. A study by Idiong (2007) estimated the technical efficiency of small scale swamp rice producers in the Cross River State, a major rice producing state in Nigeria, to be $77 \%$. The distribution of the technical efficiency showed that $70 \%$ of the farmers had technical efficiencies above $70 \%$. In a study of rice producers in Nasarawa State of Nigeria, Rahman et al. (2013) found an average technical efficiency of $62 \%$. In this study it is not clear whether the farmers produced rice in the irrigated ecology or the rainfed upland and lowland ecologies. In Kogi State of Nigeria, Ataboh et al. (2014) found mean technical efficiency of $54 \%$ for smallholder rice producers with land holdings averaging 2.3 ha. Rice production in Kogi State is encouraged in the flood plains of the rivers. Binuyo et al. (2016) found technical efficiency of $63 \%$ among rainfed lowland rice farmers in Niger State of Nigeria.

In Northern Ghana, using the SFA, Al-hassan (2008) found that technical efficiency among rice farmers was low. The technical efficiency of irrigators and non-irrigators was estimated to be 51 and 53\%, respectively. Al-hassan (2008) concluded that the low levels of technical efficiency among rice farmers suggest the presence of random shocks and managerial technical efficiency. Low levels of education, average 8 years, were observed in the study area and this might explain the managerial inefficiency. In a study conducted at Tono Irrigation Project in Nothern Ghana, Donkoh et al. (2013) found technical efficiency averaging $81 \%$. Although farmers at the Tono irrigation project are typically smallholder in terms of area, which averages 2 ha per farm, they are different from smallholders in general in that they receive inputs from the Irrigation Company of Upper Region (ICOUR), which they pay off after harvest. ICOUR also leases farm machinery like tractors, combine harvesters and different farm implements to the project farmers. Despite these advantages, the study shows that there is scope to increase technical efficiency by $19 \%$.

Our search for studies on technical efficiency of rice production in Tanzania did not yield 
any results. However, we did find a study that used the SFA to estimate the technical efficiency of sugarcane growers in Tanzania. In that study, Msuya and Ashimogo (2005) found that technical efficiency was just above $76 \%$ and about $81 \%$ for sugarcane outgrowers and nonoutgrowers, respectively at Mtibwa Sugar Estate Outgrowers Scheme. We concluded that the application of the SFA to Tanzania in general, to agriculture and specifically to rice production in estimating technical efficiency is limited, yet this could be a source of policy formulation that could assist in the country's ambition to increase rice production.

Except for a few, the common theme in the reviewed studies on technical efficiency is that there is scope for increasing production for smallholder rice producers by improving the way inputs are combined to produce output. One way to achieve this is by improving extension messages and extension contact with farmers

\section{RESULTS AND DISCUSSION}

Table II shows that the average yield on the irrigated plots was just under $3.5 \mathrm{t} / \mathrm{ha}$. This is just under the target yield for irrigated rice production in 2018. The average yield for the rainfed sample is $1.2 \mathrm{t} / \mathrm{ha}$ which is lower than the target $1.5 \mathrm{t} / \mathrm{ha}$ target for 2013 . From this data it therefore appears that the irrigated production may be more able to achieve the yield targets aspired in the NRDS than the rainfed lowland production. One of the major reasons for the gains in the irrigated system is that the irrigating farmers have adopted higher yielding improved varieties. The farmers grew Saro 5 while the lowland rainfed farmers in addition to Saro 5, grew local varieties including Super, Kihogo, Mbawambili and munguja. Fertilizer use is also higher on the irrigated plots at an average $190 \mathrm{~kg}$ per ha compared to an average $74 \mathrm{~kg} / \mathrm{ha}$ on the rainfed lowland farms.

Table II. Input use in irrigated and rainfed rice production in Tanzania

\begin{tabular}{lcc}
\hline Parameter & \multicolumn{2}{c}{ Production system } \\
\cline { 2 - 3 } & Irrigated & Rainfed \\
& $\mathrm{N}=68$ & $\mathrm{~N}=74$ \\
\hline Yield (kg/ha) & $3440(305)$ & $1190(1052)$ \\
Area (ha) & $0.41(0.0)$ & $0.96(0.78)$ \\
Fertiliser (kg/ha) & $190(29)$ & $74(181)$ \\
Labour (Mandays/ha) & $155(95)$ & $180(141)$ \\
\hline
\end{tabular}


Table III shows the characteristics of the farmers in terms of the technical efficiency effects (z's). Table III shows that all the irrigated farmers had extension contact compared to $27 \%$ on the lowland rainfed system. Farmer organisation activity is higher on the irrigated than on the lowland system. Among other things, these differences might explain the ability of the irrigated system in achieving the NRDS target yields when compared to the lowland system. There are slightly more female farmers on the irrigated plots than on the rainfed farms whereas the average age of the farmers is almost the same.

Table III. Inefficiency effects for irrigated and rainfed rice production in Tanzania (\%)

\begin{tabular}{lcc}
\hline Inefficiency effect & \multicolumn{2}{c}{ Production system } \\
\cline { 2 - 3 } & Irrigated & Rainfed \\
& $\mathrm{N}=68$ & $\mathrm{~N}=74$ \\
\hline Extension contact occurred & 100 & 27 \\
Trained & 35 & 30 \\
Member of farmer organisation/s & 91 & 45 \\
Had Credit (2012 growing season) & 0 & 7 \\
Gender (Female) & 46 & 38 \\
Education (>0 years) & 96 & 81 \\
Market access (Difficult) & 87 & 51 \\
Age in years (sdev) & $47(14)$ & $7(13)$ \\
\hline
\end{tabular}

Table IV shows the estimates of the stochastic frontier production function. On the irrigated plots, none of the farmers applied herbicide so this was excluded from the irrigated equation. As expected, land and fertilizer are significant for both equations. However, for the rainfed lowland equation fertilizer has a negative sign. It is possible that lowland rainfed farmers may be using fertilizer on local varieties whose responses to fertilizer are low. Some of the local varieties achieve high yield when fertilizer is applied but tend to have excessive straw growth and lodge thus reducing yield (Meertens, et al., 2003) 
Table IV. Stochastic frontier production function estimates by production system

\begin{tabular}{|c|c|c|c|c|}
\hline \multirow[t]{3}{*}{ Variable } & \multicolumn{2}{|c|}{ Irrigated } & \multicolumn{2}{|c|}{ Rainfed } \\
\hline & $\mathrm{N}=92(68)$ & & $\mathrm{N}=79(74)$ & \\
\hline & Coefficient & $\mathrm{t}$-Value & Coefficient & $\mathrm{t}$-Value \\
\hline Constant & 12.9 & $13.4^{* * *}$ & 8.70 & $7.81 * * *$ \\
\hline $\operatorname{Ln} A$ & 64.0 & $65.8^{* * *}$ & 1.66 & $2.47 * * *$ \\
\hline $\mathrm{LnF}$ & 10.8 & $14.6^{* * *}$ & -0.0088 & $-2.69 * * *$ \\
\hline LnL & 0.076 & 0.112 & -0.158 & -0.335 \\
\hline LnA_Sq & 66.0 & $67.5^{* * *}$ & -0.363 & -2.29 \\
\hline LnF_sq & 0.082 & 1.12 & -0.0173 & -0.240 \\
\hline LnL-SQ & -0.001 & -0.207 & -0.0258 & -0.461 \\
\hline $\mathrm{AxF}$ & 12.7 & $15.8 * * *$ & 7.18 & 0.955 \\
\hline AxL & 0.073 & 0.095 & -0.102 & -0.714 \\
\hline FxL & -0.0003 & -0.0004 & 2.31 & 0.430 \\
\hline Herbicide Dummy & N/A & N/A & -0.221 & $-1.35^{*}$ \\
\hline InsecticideDummy & 0.025 & $1.37^{*}$ & -0.0296 & -0.167 \\
\hline Constant & -0.151 & -0.223 & 2.14 & $2.21^{* *}$ \\
\hline Credit & N/A & N/A & 0.327 & 0.339 \\
\hline Sex & -0.041 & -0.120 & -0.0939 & -0.183 \\
\hline Age & -0.006 & -0.509 & -0.0173 & $-1.38^{*}$ \\
\hline Market access & 0.207 & 0.556 & 0.267 & 0.601 \\
\hline Education & -0.120 & -0.196 & 0.115 & 0.173 \\
\hline Farmer organisation & -0.367 & -0.916 & -0.692 & $-1.70 * *$ \\
\hline Extension & N/A & N/A & -0.33 & -0.480 \\
\hline Train & -0.651 & $-1.38^{*}$ & -1.33 & $-2.12 * *$ \\
\hline Sigma Squared & 4.87 & $2.69^{* * *}$ & 1.11 & $6.07 * * *$ \\
\hline Gamma & 0.898 & $18.9^{* * *}$ & 0.999 & $29500 * * *$ \\
\hline
\end{tabular}

$* * *=$ Significant at $\alpha=0.01 ; * *=$ Significant at $\alpha=0.05 ; *=$ Significant at $\alpha=0.1$

Table $\mathrm{V}$ shows that the average technical efficiency of the irrigated farmers is $96 \%$ compared to an average 39\% for the rainfed lowland system. For the irrigated system, there are no farmers with technical efficiency less than $80 \%$. The high technical efficiency indicates that in order to achieve the aspired rice production targets, the opportunity for increasing production therefore lies in changing the production technology. The levels of fertilizer used by the irrigating farmers seem to indicate that there is potential for increasing fertilizer use thus 
increasing yields. Breeding new higher yielding varieties than the ones currently used also offers opportunities for shifting the production frontier to the right. On the rainfed lowland system there is scope for increasing the technical efficiency of production. Most of the rainfed lowland rice producers achieve technical efficiencies less than 50\%. Only about 20\% achieve technical efficiencies higher than $80 \%$. For the rainfed lowland production a combination of increasing technical efficiency through say better extension and also changing the technology through say improved varieties could be adopted in order to achieve the aspired increases in rice production.

Table V. Frequency distribution (\%) of technical efficiency for rainfed with no access to irrigation and modern communal irrigation farmers

\begin{tabular}{|c|c|c|}
\hline \multirow[b]{2}{*}{ Technical efficiency Interval } & \multicolumn{2}{|c|}{ System type } \\
\hline & Irrigated & Rainfed \\
\hline$<10$ & 0 & 14 \\
\hline$\geq 10<20$ & 0 & 23 \\
\hline$\geq 20<30$ & 0 & 11 \\
\hline$\geq 30<40$ & 0 & 15 \\
\hline$\geq 40<50$ & 0 & 8 \\
\hline$\geq 50<60$ & 0 & 3 \\
\hline$\geq 60<70$ & 0 & 4 \\
\hline$\geq 70<80$ & 1 & 4 \\
\hline$\geq 80<90$ & 2 & 10 \\
\hline$\geq 90<100$ & 97 & 9 \\
\hline Total & 100 & 100 \\
\hline Mean technical efficiency & 96 & 39 \\
\hline $\mathrm{N}$ & $92(68)$ & $79(74)$ \\
\hline
\end{tabular}

\section{CONCLUSION}

The government of Tanzania is committed to increasing rice production. The rice production targets that are aspired are articulated in the NRDS which summarises the rice production plans up to 2018. Tanzania produces rice from two major ecologies; namely irrigated and rainfed lowland. Currently most of the rice is produced from the rainfed lowland but the NRDS aspires to reverse this trend by having more rice produced under irrigation by 2018 . This study evaluated the performance of irrigated and rainfed lowland rice production using technical efficiency. The technical efficiency of irrigated rice production is very high averaging $96 \%$ with 
all farmers achieving higher than $80 \%$ technical efficiency. This means that, if more land can be developed for irrigation as aspired by the NRDS, it is possible to attain the aspired targets under irrigation. There is also scope for input intensification which could lead to even more gains from irrigated rice production. The technical efficiency of rainfed lowland rice production is very low averaging $39 \%$. This shows that there are gains to be made by increasing the technical efficiency at current input levels. We recommend a strengthening of the extension system for the rainfed system. All farmers on the irrigated system had extension contact but only $27 \%$ of farmers on the rainfed lowland system had extension contact. Improving this is likely to improve the technical efficiency of rainfed farmers. Gelan and Muriithi (2012) and Rahman et al. (2013) also conclude that strengthening extension can improve the technical efficiency of rice farmers. It is also possible to change the production technology of rainfed farmers through improved rice varieties which are more responsive to fertilizer.

\section{REFERENCES}

Adkins LC, Moomaw RL, Savvides A. 2002. Institutions, Freedom, and Technical Efficiency. Southern Economic Journal 69(1), 92-108.

Aigner D, Lovell CAK. 1977. Formulation and Estimation of Stochastic Frontier Production Function Models. Journal of Econometrics 6: 21-37.

Al-hassan S. 2008. Technical Efficiency of Rice Farmers in Northern Ghana. AERC Research Paper 178. African Economic Research Consortium. Nairobi, Kenya.

Ataboh OE, Umeh JC, Tsue PT. 2014. Determinants of Technical Efficiency among Rice Farmers in Kogi State, Nigeria. Journal of Agriculture and Sustainability 6: 39-49.

Battese GE, Coelli TJ. 1995. A Model for Technical Inefficiency Effects in a Stochastic Frontier Production Function for panel data. Empirical Economics 20: 325-332.

Binuyo G, Abdulrahman S, Yusuf O, Timothy AJ. 2016. Technical Efficiency of Rain-fed Lowland Rice Production in Niger State, Nigeria. Asian Journal of Agricultural Extension, Economics \& Sociology 9(4): 1-12.

Battese GE. 1992. Frontier production functions and technical efficiency: a survey of empirical applications in agricultural economics. Agricultural Economics 7:185-208.

Boateng NA. 2014. Technical efficiency and primary education in South Africa:evidence from sub-national level analyses. South African Journal of Education 34(2) 1-18.

Bravo-Ureta BE, Pinheiro AE. 1993. Efficiency analysis of developing country agriculture: a review of the frontier function literature. Agricultural and Resource Economics Review 22: $88-101$. 
Bucheyeki TL, Shennkalwa E, Kadadi D, Lobulu J. 2011. Assessment of Rice Production Constraints and Farmers Preferences in Nzega and Igunga Districts, Advances in Developmental Research, 2: 30-37.

Gebremichael BZ, Gessesse HT. 2016. Technical efficiency of Microfinance Institutions (MFIs) Does ownership matter? Evidence from African MFIs. International Journal of Development Issues 15(3):224-239. DOI:10.1108/IJDI-04-2016-0026.

Gelan A, Muriithi BW. 2012. Measuring and explaining technical efficiency of dairy farms: A case study of smallholder farms in East Africa. Agrekon 51(2):53-74.

Giroh DY, Moses JD, Balogun FE, Odekina FO. 2012. Analysis of the Factors Influencing the Technical Efficiency of Women Rubber Tappers in the Rubber belt of Nigeria. Gender \& Behaviour 10(2):4678-4686.

Donkoh SA, Ayambila S, Abdulai S. 2013.Technical Efficiency of Rice Production at the Tono Irrigation Scheme in Northern Ghana. American Journal of Experimental Agriculture 3(1): 25-42.

Government of Tanzania. 2009. National Rice Development Strategy. Ministry of Agriculture Food Security and Cooperatives. Dar es Salaam, Tanzania.

Idiong IC. 2007. Estimation of Farm Level Technical Efficiency in Smallscale Swamp Rice Production in Cross River State of Nigeria: A Stochastic Frontier Approach. World Journal of Agricultural Sciences 3 (5): 653-658.

Kodde DA, Palm FC. 1986. Wald criteria for jointly testing equality and inequality restrictions. Econometrica 54 (5): 1243-1248.

Makombe G, Makadho JM, Sampath RK. 1998. An analysis of the water management performance of small holder irrigation schemes in Zimbabwe. Irrigation and Drainage Systems 12: 253-263.

Makombe G, Meinzen-Dick R, Davies SP, Sampath RK. 2001. An Evaluation of Bani (Dambo) Systems as a Smallholder Irrigation Development Strategy in Zimbabwe. Canadian Journal of Agricultural Economics 49: 203-216.

Makombe G, Namara R, Hagos F, Awulachew SB, Ayana M, Bossio D. 2011. A comparative analysis of the technical efficiency of rain-fed and smallholder irrigation in Ethiopia. International Water Management Institute. doi:10.5337/2011.202. Colombo, Sri Lanka.

Makombe G, Namara RE, Awulachew SB, Hagos F, Ayana M, Kanjere M. 2017. An analysis of the productivity and technical efficiency of smallholder irrigation in Ethiopia. Water $S A, 43(1): 48-57$.

Maurice DC, Joseph M, Garba A. 2015. Analysis of Technical Inefficiency In Food Crop Production Systems Among Small-Scale Farmers in Some Selected Local Government 
Areas of Adamawa State, Nigeria. ATBU. Journal of Science, Technology \& Education (JOSTE) 3(1):1-14.

Meertens HCC, Kajiru GJ, Ndege LJ, Enserink HJ, Brouwer J. 2003. Evaluation of on-farm soil fertility research in the rainfed lowland rice fields of Sukumaland, Tanzania', Expl Agric 39 : 65-79.

Meeusen W, Van den Broeck J. 1977. Efficiency estimation from Cobb-Douglas production Functions with composed error. International Economic Review 18(2):435-43.

Mkhabela T. 2005. Technical Efficiency in a Vegetable Based Mixed-Cropping Sector in Tugela Ferry, Msinga District, Kwazulu-Natal. Agrekon 44(2):187-204

Msuya E, Ashimogo G. 2005. Estimation of Technical Efficiency in Tanzanian Sugarcane Production: A Case Study of Mtibwa Sugar Estate Outgrowers Scheme. Economic and Development Papers, Mzumbe University 1 (1) 28-46 Online at http://mpra.ub.unimuenchen.de/3747/

Mujeyi K, Siziba S, Sadomba WZ, Mutambara J. 2016. Technical efficiency of informal manufacturing sector enterprises: Evidence from the informal metal industry of Zimbabwe. African Journal of Science, Technology, Innovation and Development 8 (1):12-17.

Ogundele OO, Okoruwa VO. 2006. Technical efficiency differentials in rice production technologies in Nigeria. AERC Research Paper 154. Nairobi: African Economic Research Consortium

Thiam A, Bravo-Ureta BE, Rivas TE. 2001. Technical efficiency in developing country agriculture: a meta-analysis. Agricultural Economics 25: 235-243.

Rahman SA, Onuk EG, Oyewole SO. 2013. Analysis of Technical Efficiency of Rice Farm in Nasarawa State, Nigeria. International Journal of Agriculture and Biosciences 2(5): 266269.

Sinha SK, Talati J. 2006. Productivity impacts of the system of rice intensification (SRI): A case study in West Bengal, India. Agricultural water management 87: 55-60.

Van Heerden C, Van Der Westhuizen G. 2008. The cost of banking services and the technical efficiency of a South African bank The Journal for Transdisciplinary Research in Southern Africa 4(2):401-417.

Wang H, Schmidt P. 2002. One-Step and Two-Step Estimation of the Effects of Exogenous Variables on Technical Efficiency Levels. Journal of Productivity Analysis 18: 129-144. 